The Agriculturists 13(1): 173-188(2015) ISSN 2304-7321 (Online), ISSN 1729-5211 (Print)

Review Article

\title{
Challenges of Seed Potato (Solanum tuberosum L.) Production and Supply System in Bangladesh - A Review
}

\author{
Md. Rayhan Shaheb ${ }^{1 *}$, M. Mahbuba Begum², Kabir Uddin Ahmed², \\ Mahmudul Islam Nazrul ${ }^{1}$ and Siert G. Wiersema ${ }^{3}$ \\ ${ }^{1}$ On-Farm Research Division, Bangladesh Agricultural Research institute (BARI), Sylhet-3100, \\ Bangladesh; ${ }^{2}$ Tuber Crops Research Centre, BARI, Joydebpur, Gazipur - 1701, Bangladesh; \\ ${ }^{3} \mathrm{CDI}$, Wageningen UR, The Netherlands \\ *Corresponding author and Email: smrayhan_bari@yahoo.com
}

Received: 17 February 2014

Accepted: 06 June 2015

\begin{abstract}
Potato (Solanum tuberosum L.) is an important vegetable that plays a vital role in global food and nutritional security and alleviation of poverty, especially in Bangladesh. Although, the soil and climatic conditions of Bangladesh are favourable for potato cultivation, every year production is hampered due to use of low quality seeds. Seed potato industry is developing in Bangladesh. However, only $5-10 \%$ quality seeds are being produced and used by the potato farmers. Quality seeds alone can contribute to increased yield by $15-20 \%$. Both public and private sectors together supply only $5 \%$ quality seed potato and the rest $95 \%$ is almost of low quality produced by the farmers themselves. In prioritizing different issues of agriculture, challenges of production and supply of quality seed to the farmers should be considered as a top priority issue. For increasing quality seeds, the whole seed system needs to be reviewed. The present work was an attempt to review the seed potato production systems, supply system and also to identify the possible challenges and policy implications in regards of the problems on seed potato in Bangladesh.
\end{abstract}

Keywords: Seed potato production, seed supply systems, quality seeds, seed industry

\section{Introduction}

Potato (Solanum tuberosum L.) is a popular tuber crop and in terms of production, which ranks third as food crop in Bangladesh (BBS, 2012). It is also used in processing industries at a small scale and utilizes between 80,000 to 100,000 tons of potatoes annually (Hossain et al., 2008). The global total potato crop production exceeds 300 million metric tons and more than a billion people worldwide consume potatoes, which is also ranked third (CIP:WPA, 2009).
Johnson et al. (2010) reported that potato tuber has been used for processing, mainly frozen, chips and dehydrated products. It is a cheap source of nutrients, income and employment to guarantee food security (Lutaladio and Castaidi, 2009). In Bangladesh, 461 thousand hectares of cultivable land is under potato cultivation and the country produced 8.3 million tones of potato in 2010-2011 with an average yield 18.0 tha $^{-1}$ (BBS, 2012). The average yield of potato in Bangladesh (18.0 tha ${ }^{-1}$ ) is very low compared to those in other potato producing countries 
(Anonymous, 2008). Hossain et al. (2008) reported that the national average yield of potato is also very low (19.07 tha $^{-1}$ ) compare to its potential yields of $30-40$ tha $^{-1}$ due to lack of quality seed, cultivation of indigenous potato tubers and high price of quality seed potato. Bangladesh is the third largest potato producer in Asia, and stands sixth in the world (FAO, 2010). In Bangladesh, potato production in the past has been increased by 5 percent per annum (Islam et al., 2000). With the introduction of modern varieties and appropriate management techniques, this production can be doubled. It is also possible to increase potato production both vertically and horizontally (Uddin et al., 2009). Low quality seed is one of the major problems for potato cultivation in Bangladesh (Hossain et al., 2011a). Suitable varieties combined with high-quality seed potatoes is an essential prerequisite for profitable and sustainable cultivation (NIVAP, 2011). Considering the seed rate of 1.5 tha $^{-1}$, total seed potato requirement per year is approximately 0.6 million tons in Bangladesh (BADC, 2012) of which only $5 \%$ is supplied by private and public sectors (Karim, 2009).

Quality seeds can alone contribute to the increased yield by 15 - 20\% (BADC, 2012). Farmers are facing various problems to produce seed potato viz. lack of quality seed, disease and insect problem, high price of quality seed, lack of knowledge on quality seed potato production etc. (Shaheb, 2013).

This review aims to: (i) summarize the present status of seed potato production and supply systems; (ii) determine the farmers' problems towards seed potato production; and (iii) identify strategies of increasing seed potato production and supply systems in Bangladesh.

\section{Discussions}

\subsection{A brief history of potato cultivation in Bangladesh}

By 1920, the first commercial production of the potato took place in the country (Islam, 1983). Research was conducted in 1960 on fertilizer applications, seed degeneration, mulching, planting techniques and storage (Ahmad, 1977). Before independence and during the colonial period, only seed potatoes of indigenous varieties were used as seed potato for cultivation. Seeds of modern high yielding potato varieties were first imported from the Netherlands in 1960 and continued there after (Kadian et al., 2000).

\subsection{Present status of potato production}

National production trends for the last five decades are summarized in Figure 1. Potato yield, area of harvest and production were slightly higher in seventy decade compared to sixty decade. These parameters remained almost stable with some fluctuations up to ninety decade and after that, dramatically increased four folds more in production, two folds more in area harvest and 1.5 times more in yields amounting 15 tha $^{-1}$ in 2007 from 10 tha $^{-1}$ in 1990 (CIP:WPA, 2009). Figure 2 shows that per capita production of potato was also increased over the previous decades. However, up to the early 2000, developed countries were the major producers and consumers of potato but during the last decade developing countries' production surpassed that of the developed countries (Walker et al., 2011).

At present, Bangladesh is producing around 8 million tons of potatoes per year (BBS, 2012). In 2010-11, total requirement of seed potato was 0.6 million tons, of which only 20000 tons (3\%) quality seeds were produced by Bangladesh Agriculture Development Corporation (BADC, 2012). The potato growing area and production during 2006-07 to 2010-11 are shown in Table 1. Both area and production of potato were increasing except in 2008-09.

In Bangladesh, the supply of high quality seed potatoes including import and local multiplication by private sector covers only $5 \%$ of the total seed requirements (Ahmed, 2013). The country needs around 1 million tons seed potato each year, of which only 2-3\% is supplied by the government (ISAAA, 2010). The public sector is trying to improve seed quality through 
formal seed system and private sector is coming up with added quantities with certified seeds and truthfully labeled seeds (TLS). Sixty six percent of the seeds used by the farmers are of no definite quality.

Bangladesh Agricultural Development Corporation (BADC) has been supplying only 20,000 tons of quality seed-potato among the farmers as against the annual demand of about 0.6 million tons (BADC, 2012). However, the availability of affordable high-quality seed potatoes is the major constraint for potato production systems worldwide (Lutaladio et al., 2009; Struik and Wiersema, 1999). The present supply of seed potatoes in Bangladesh is presented sector wise in Figure 3.

The Ministry of Agriculture has given attention to increase the production of tuber crops especially, production of quality potato seeds, their preservation and distribution. Bangladesh is trying to strengthen potato sector through different agencies like Bangladesh Agricultural Research Institute (BARI), Bangladesh Agricultural Development Corporation (BADC), Department of Agriculture Extension (DAE), Seed Certification Agency (SCA) etc. The main aims is to produce breeder seeds of potato through tissue culture technology in a bid to reduce import dependence, collecting local and foreign germplasm to innovate high-yielding, salt- and drought-tolerant varieties and so on. At the same time, the government is also encouraging private sector to strengthen stable seed potato production and supply system etc. However, import of higher standard and grade potato seed followed by local multiplication would rapidly increases of seed production and supply in Bangladesh.

\subsection{Potato varieties}

BARI has already introduced 58 potato varieties (BARI, 2014), most of which are introduced from the Netherlands; some varieties are developed with clone materials collected from International Potato Centre (CIP) and some of them are also developed by BARI. At present,
Daimant, Cardinal and Granola are the most popular varieties due to their higher yields, taste and acceptability. There are some local potato varieties called 'Deshi' in Bangladesh which are cultivated by farmers because of their taste and keeping quality. The best example of these are, Sheel Bilatee: mostly cultivated in Rangpur, with oblong reddish tubers; Lal Sheel (Lal Madda and Bograi): grown primarily in Bogra with rounder and reddish tubers; Lal Pakri: widely grown in Dinajpur, Bogra, and Sirajganj districts with round, also reddish tubers and Du Hajari: mostly cultivated in the Chittagong area, with round and more pale tubers. The tubers of indigenous varieties are usually small in size, sticky, having good taste, better keeping quality and storability. In spite of poor yields, some of the local varieties are still being cultivated because of their taste and cooking qualities.

According to Miah et al. (2013), 70.87\% farmers believe that the current potato yield (21.5-22.67 tha $^{-1}$ ) can be further increased through introducing new HYVs in Bangladesh. Although Khurana et al. (2003) reported that the more popular HYVs are Cardinal, Diamant, Kufri Shindhury, Ailsa, Baraka, Chamak, Cleopatra, Dheera, Granola, Heera, Multa, Origo, Patrones and so on are widely used, but presently Cardinal, Diamant and Granula are available in farmers' field. Some newly released varieties like Asterix, Courage and Ladi Rosseta are gaining popularity as processing purpose in the country.

\subsection{Potato research and development}

Tuber Crops Research Centre (TCRC) of BARI is mandated for conducting research on potato development (BARI, 2014). BARI Alu 35, BARI Alu 36 and BARI Alu 37, BARI Alu 40 and BARI Alu 41 are the varieties produced by hybridization from TCRC (Mondal et al., 2011). Two true potato seed (TPS) varieties were also released by BARI such as BARI TPS- 1 and BARI TPS- 2 both from the CIP materials. The TPS technology found to have a higher benefitcost ratio (BCR) than the traditional technology (Islam et al., 2000). Attempts have been taken by 
the scientists to introduce True Potato Seed (TPS) technology to reduce substantial production costs and increase potato productivity. Beside BARI, several private agencies like Bangladesh Rural Advancement Committee (BRAC), Lal Teer, Supreme Seeds are also involved in potato research, but at a limited scale. However, little progress is achieved so far to produce disease free quality seeds. Thus, the development and availability of appropriate varieties and crop production technologies is crucial to meet an increased potato demand at affordable prices for the poor (CIP, 2009). Research and extension on seed potato technology needs to give more attention to produce disease free seeds.

\subsection{Seed industry of Bangladesh at a glance}

In the private sector, there are more than 100 companies with over 5000 registered seed dealers operating in the country (Ahmed, 2013). The recent expansion of the private seed companies has resulted in the engagement of thousands of contract farmers into the formal seed production chain, leading to improved livelihoods amongst the rural community. However, seed potato should be grown by contract farmers and seed companies under the laws and full control and monitoring by the government. The capacity of both public and private sector should be strengthened for the improvement of seed system (BADC, 2012).

\subsection{Seed potato production systems in Bangladesh}

\subsubsection{Management approach}

Seed potatoes are produced in Bangladesh following both formal and informal approaches.
The formal approach includes seed production by the public and private sector companies. Formal system follows the rules of National Seed Board (NSB). The system involves clonal multiplication from imported seeds, or from tissue culture derived plantlets, and through the usage of true potato seeds (TPS). However, TPS is being used by a limited number of farmers. In the public sector, TCRC, BARI produces breeder seeds and or pre-foundation seed under net house, which are supplied to BADC for multiplication and distribution to the farmers (Flow chart 1).

The Breeder Seed Production Centre (BSPC) of the TCRC produces and supplies breeder seed to $\mathrm{BADC}$ for further multiplication to produce foundation and certified seed. For the 2011-12 crop season, the BSPC produced 285.05 metric tons breeder seed in net houses for BADC. Besides this, the breeder's seed and the foundation seed are also supplied to different local NGOs and farmers. The schematic diagram of the production and supply methods is furnished in Flow chart 2.

The BADC produces foundation seeds from prefoundation at the seed farms during low aphid periods. The foundation seed is given to contract growers for further multiplication of certified seed. The BADC sells certified seed to farmers through authorized dealers. The informal approach of seed potato production includes multiplication, maintenance and exchange of seed potatoes by the farmers. The performance of self produced and stored potato seeds by farmers are poor compared to the seeds from BADC (Shahriar et al., 2013).

Table 1. Area (hectare) and production (tons) of potato in 2006-07 to 2010-2011

\begin{tabular}{|c|c|c|c|c|c|c|c|c|c|c|}
\hline Potato & \multicolumn{2}{|c|}{ 2006-07 } & \multicolumn{2}{|c|}{ 2007-08 } & \multicolumn{2}{|c|}{$2008-09$} & \multicolumn{2}{|c|}{$2009-10$} & \multicolumn{2}{|c|}{$2010-11$} \\
\hline Variety & Area & Prod. & Area & Prod. & Area & Prod. & Area & Prod. & Area & Prod. \\
\hline Local & 84086 & 818017 & 81433 & 886109 & 78317 & 561907 & 74588 & 806171 & 74642 & 869787 \\
\hline HYV & 261106 & 4348655 & 320734 & 5761669 & 317587 & 4706420 & 360320 & 7124069 & 385921 & 7456602 \\
\hline Total & 345192 & 5166672 & 402167 & 6647778 & 395904 & 5268327 & 434908 & 7930240 & 460563 & 8326389 \\
\hline $\begin{array}{l}\text { Yield } \\
\left.\text { (tha }^{-1}\right)\end{array}$ & \multicolumn{2}{|c|}{14.32} & \multicolumn{2}{|c|}{16.31} & \multicolumn{2}{|c|}{18.25} & \multicolumn{2}{|c|}{18.25} & \multicolumn{2}{|c|}{18.09} \\
\hline
\end{tabular}


Table 2. Quality standards as regulated by Seed Certification Agency of Bangladesh

\begin{tabular}{|c|c|c|c|c|}
\hline \multirow{2}{*}{$\begin{array}{l}\text { SL. } \\
\text { No. }\end{array}$} & \multirow[t]{2}{*}{ Factors } & \multicolumn{3}{|c|}{ Seed Standard } \\
\hline & & Breeder & Foundation & Certified/TLS \\
\hline (A) & Seed Standard & & & \\
\hline 1. & $\begin{array}{l}\text { Potatoes with any kind of damage or secondary growth } \\
\text { are not acceptable }\end{array}$ & & & \\
\hline 2. & Mixture of other varieties (Max. \%) & 0.20 & 0.20 & 0.20 \\
\hline 3. & Grades of seed potato: & & & \\
\hline & a. $28 \mathrm{~mm}-35 \mathrm{~mm}$ diameter & $\sqrt{ }$ & $\sqrt{ }$ & $\sqrt{ }$ \\
\hline & b. $36 \mathrm{~mm}-45 \mathrm{~mm}$ diameter & $\sqrt{ }$ & $\sqrt{ }$ & $\sqrt{ }$ \\
\hline & c. $46 \mathrm{~mm}-55 \mathrm{~mm}$ diameter & $\sqrt{ }$ & $\sqrt{ }$ & $\sqrt{ }$ \\
\hline
\end{tabular}

4. Tubers not conforming to specific size of seed shall not exceed more than $5 \%$ by number.

5. The above mentioned grades will not be applicable for tuberlets produced from true potato seed (TPS)

(B) Field Standard

1. Isolation distance (In meter)

a. From non-seed potato crop

b. From other solanacious crop

$30.00 \quad 30.00 \quad 30.00$

2. Other varieties (Maximum \% by no.)

$\begin{array}{lll}15.00 & 15.00 & 15.00\end{array}$

3. Other crops (Maximum \% by no.)

4. Obnoxious weeds (maximum \%)

0.20

0.20

0.20

0.00

0.00

0.00

5. Disease (Infection by seed borne pathogen: Max. \% of infected plants)

\begin{tabular}{llll} 
a. Late blight (Phytopthora infestans) & 0.00 & 0.00 & 0.00 \\
b. Leaf roll (PLRV) & 0.00 & 0.50 & 2.00 \\
c. Mosaic (PMV) & 0.00 & 0.10 & 1.00 \\
d. Ring rot & 0.00 & 0.00 & 0.00 \\
\hline
\end{tabular}

Source: www.badc.gov.bd

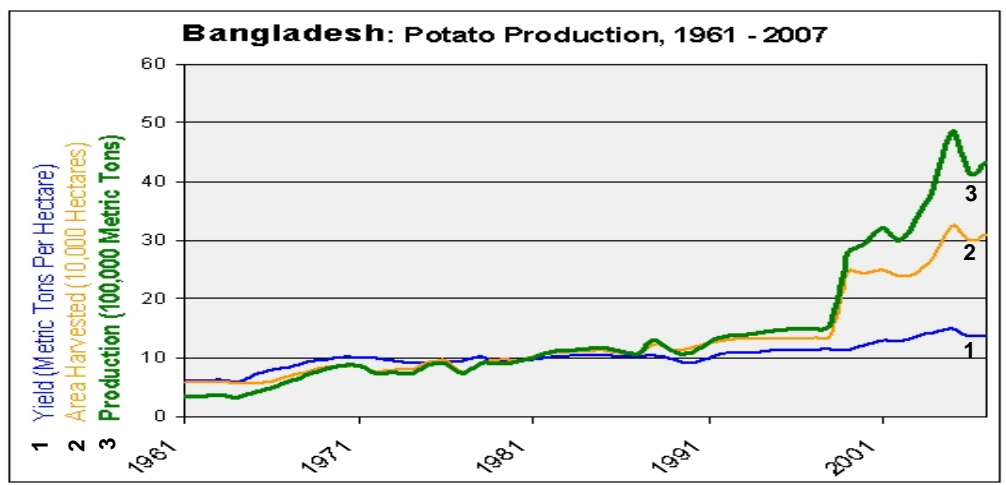

Figure 1. Yield, area and production of potato in the last 5 decades of 1961-2007 (CIP:WPA, 2009) 


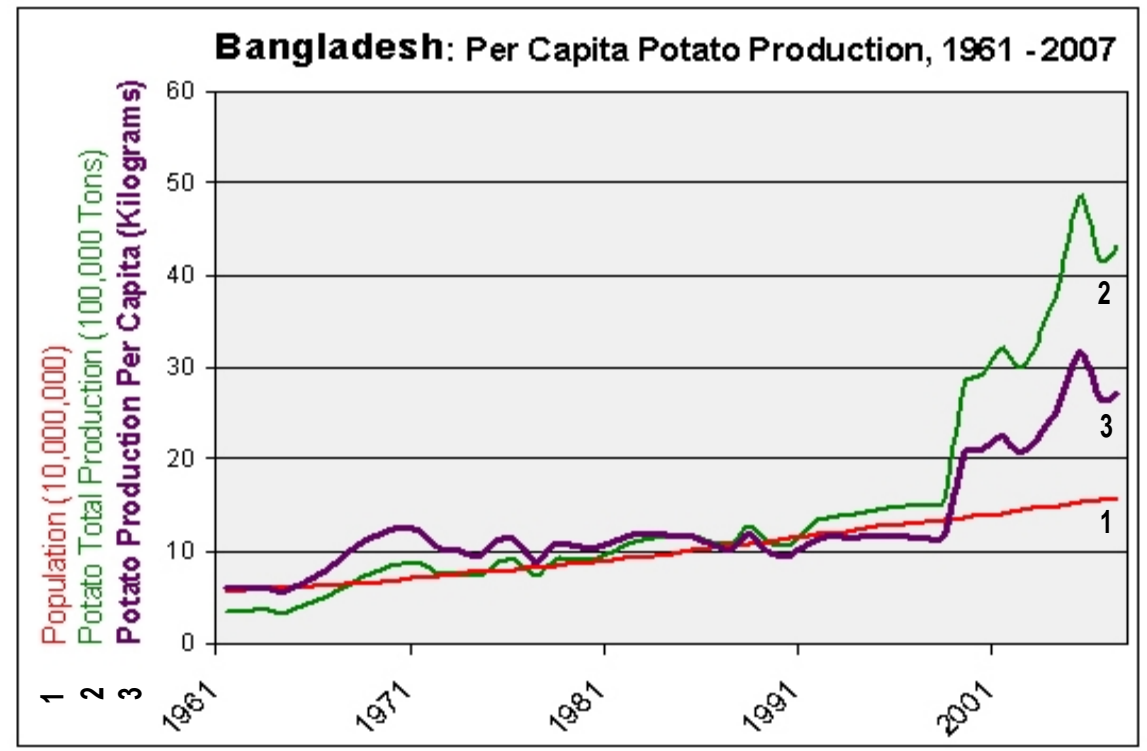

Figure 2. Per capita potato production in the last 5 decades of 1961-2007 (CIP:WPA, 2009).

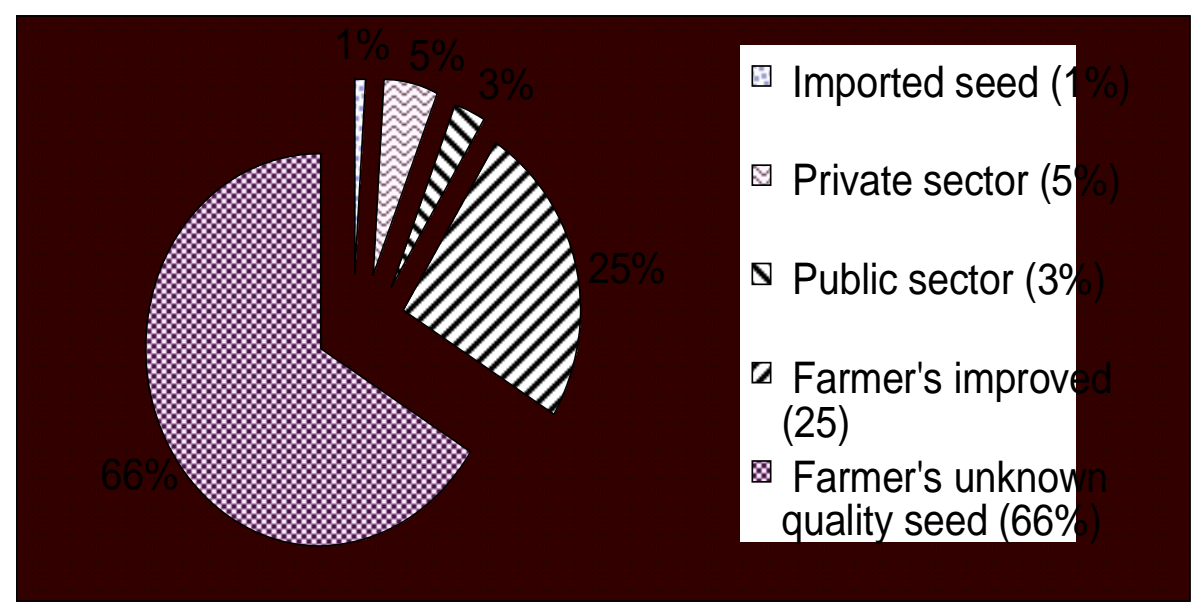

Figure 3. Estimation of supply of seed potatoes in Bangladesh by different sectors (Source: Ahmed, 2013) 


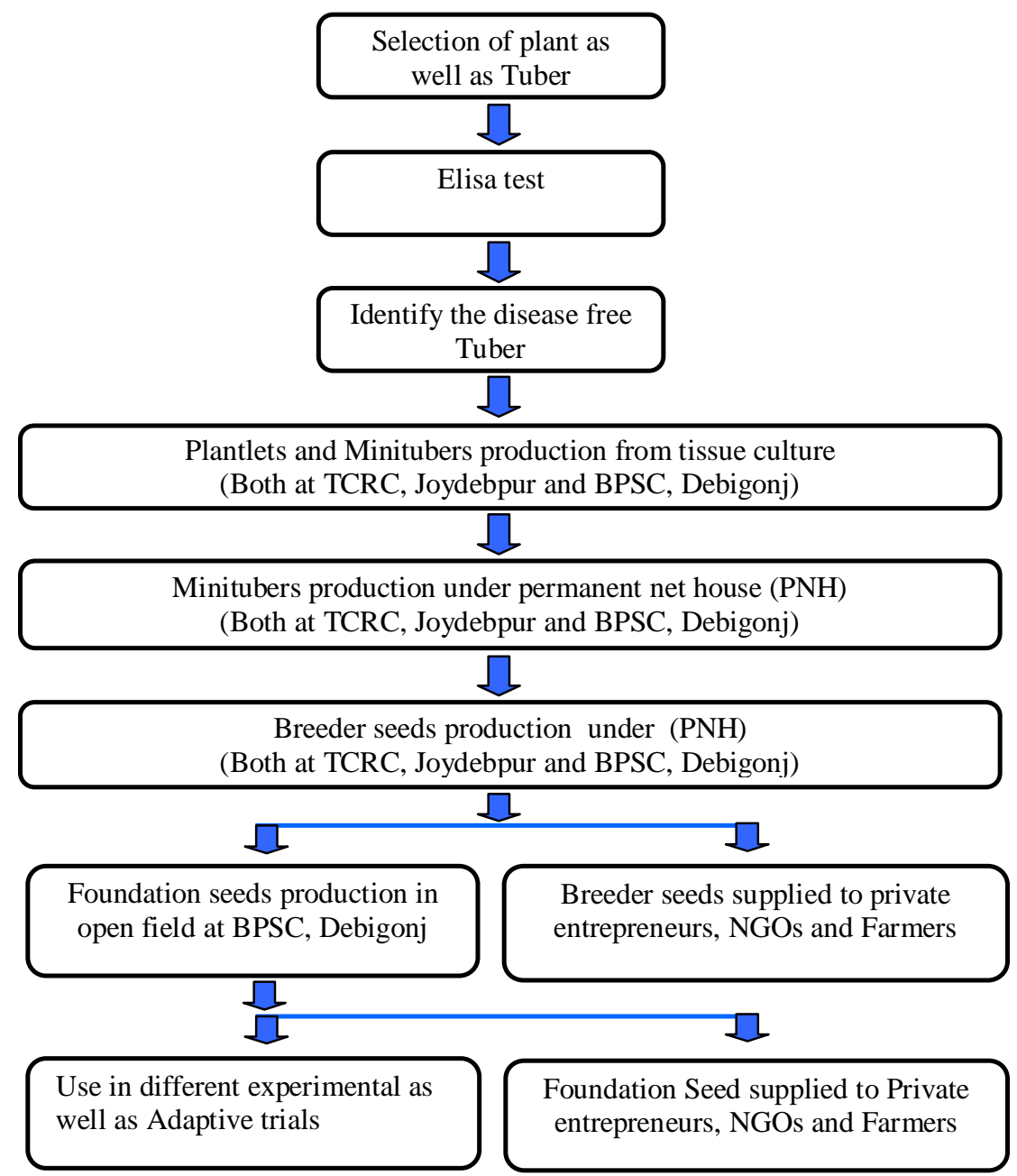

Flow chart 1. The formal approach of seed potato production followed by Research Centre, Bangladesh. 


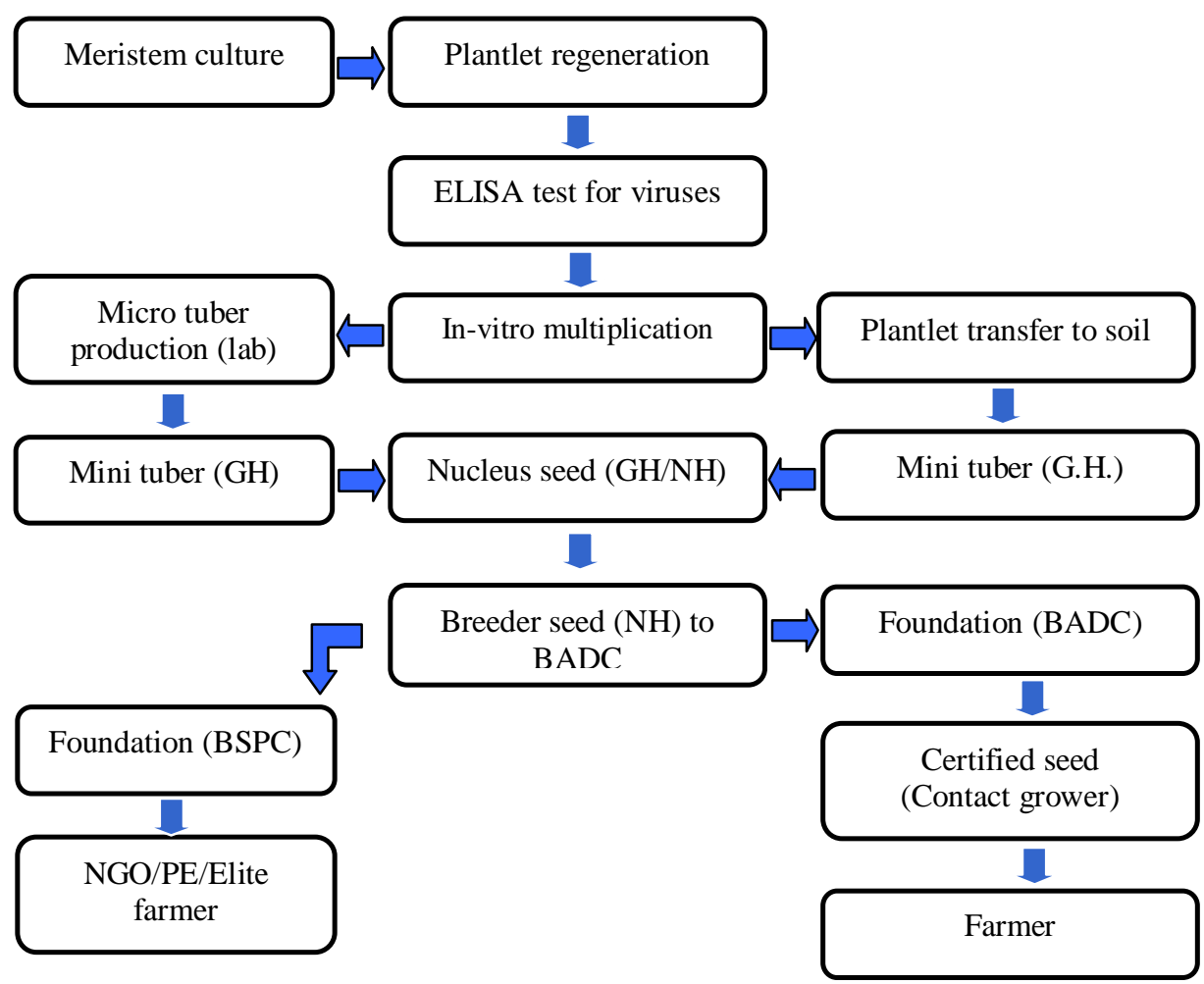

Flow chart 2. The formal approach of seed potato production in the public sectors in Bangladesh.

Seed production systems are often done by the adoption of Seed Plot Technique (Begum et al., 2013) and positive selection through which vigorous, apparently disease free healthy-looking mother plants, showing good production characteristics (Gildemacher et al., 2007) are identified and tubers collected from them and seeds are used for the next season cultivation.

\subsubsection{Technical approach}

Production of seed potato involves adoption of specialized cultivation and management techniques beyond standard practices for table purpose potato production. Thus due attention is paid just from sourcing of initial planting materials of proper physiological age and all the operations in the field for proper growth, development, pre-harvest and post-harvest handling including storage for maintenance of quality seed potatoes. Huda (2001suggested that seed quality is a multiple concept and thereby is affected by multiple factors during production, harvesting, processing and storage. For a successful seed production program, it is important to reduce the risks of virus contamination by rouging out infected plants and by adjustment of planting time and harvesting before the arrival and building up of high population of aphids in the field. However, good quality of potato seeds can be ensured 
significantly by positive selection. Selecting seed potatoes from healthy-looking mother plants (positive selection) assures lower incidences of PLRV (39\%), PVY (35\%) and PVX (35\%). Positive selection out-yielded farmer selection by $30 \%$ irrespective of the agro-ecology, crop management, soil fertility, variety and quality of the starter seed, which may benefit all smallholder potato producers who select seed potatoes at same stage from their own fields, and thus could be incorporated routinely in agricultural extension efforts (Gildemacher et al., 2011; Schulte-Geldermann et al., 2012).

In Netherlands, all seed potatoes are produced following a flush-out systems. Starting from clone selection, seeds further multiplied in to different categories, each further subdivided in a number of classes. The seed lot normally stays in one class for one generation and downgrades automatically with successive multiplications (NIVAA, 2011). The most important yield determining factor in potato cultivation is the quality seed tubers (Lutaladio et al., 2009; Struik and Wiersema, 1999). Proper seed production systems are crucial for a productive and effective potato industry (Struik and Wiersema, 2012).

\subsection{Seed supply system in Bangladesh}

\subsubsection{The "Informal" seed system}

The informal seed system is commonly practiced by the farmers to produce seed potato. A majority of the farmers buy seeds from other farmers, traders, open markets or cold storage owners (CIP: WPA, 2009). The quality of those seeds is very poor. Since potato is cultivated only as a winter crop, tubers retained for seeds must be stored for several months till the next planting. The limited number of cold storage in Bangladesh provides facilities to store seed potatoes. Low qualities of these seed are one of the major problems for potato cultivation in Bangladesh. Supply of quality seeds to the farmers should be ensured by strengthening seed production and distribution system both in public and private sectors (Shahriar et al., 2013).
The intermediaries in the potato seed marketing systems are farmers, cold storage managers and traders (Bepari-big trader), Faria (petty trader), Aratder (commission agent), Paiker (wholesaler) and retailer, private seed growers etc. Most of them are selling seeds having seed borne pathogen (disease), lower germination etc. Likewise, every year potato production is hampered due to limited supply of quality seeds, lack of sound knowledge of seed production technologies; lack of awareness both farmers as well as seed producers, poor development of seed potato industry etc. However, the informal seed system should prioritize improving seed quality by increasing awareness and skills of farmers, improving seed tuber quality of early generations and market access.

\subsubsection{The "Formal" seed system}

The formal system refers to seed tubers production and distribution by state-sponsored institutions, possibly with involvement of some private sector. Seeds from the formal system has generally been subject to an inspection and control process intended to assure that the seed is of the variety claimed with low incidence of disease or pest infestation, such seed is referred to as "certified seed", which are produced from "pre-foundation" and "foundation" seeds. The TCRC of BARI produces breeder seed of popular variety and use these to produce 500 to 700 tons pre-foundation seeds annually which are supplied to the BADC. Then BADC multiplies these under controlled condition and supplies to the farmers as certified seeds. BADC is able to produce about 6,000 tons of certified seed each year, approximately 7.3 percent of the required tuber seed of HYVs grown in Bangladesh (about 4.8 percent of the nation's requirement (Khurana et al., 2003). To the extent that if subsequent generations of certified seed are sown, beyond just one cropping season, the quantitative impact of certified seed would be considerably more (Thiele, 1998). However, both private and public sector together supply only $9 \%$ quality seed of the total requirement and rest $91 \%$ is the low quality seed potato (Ahmed, 2013). 
Another alternative that has been explored in Bangladesh to increase the availability of high quality disease-free seed tubers is the production of TPS. With the help of CIP, BARI has contributed several families of potato cultivars to this effort, but one challenge remains finding TPS families which meet farmers' preferences at an affordable price (Ilangantileke et al., 2000). However, these are being transferred through private seed growers to the farmers. The alternative and formal seed systems should prioritize for improving the production capacity of quality seeds by availing new varieties, designing quality control methods and improving farmer's awareness. Alternative seed system is a community based system of seed potato production that can help to strengthen seed industry successfully. In Ethiopia, to improve overall seed potato supply experts postulated coexistence and linkage of the three seed systems and development of self-regulation and selfcertification in the informal, alternative and formal cooperative seed potato systems (Adane Hirpa et al., 2014).

\section{Why alternative seed system?}

The alternative seed system (ASS) in seed potato production is a community base system that supplies potato seed tubers produced by local farmers under the financial and technical support from NGOs and breeder seed production centers. Self-help development international (SHDI) and the FAO seed security project (Getachew and Mela, 2000; Mulatu et al., 2005) can be mentioned as good examples of this. Attention may also be given to form farmers' research groups and farmers' field schools in the major potato growing areas of Bangladesh which would be involved in seed potato production. These groups may be formed by research institutes. Gildemacher et al. (2009) asserted that the alternative seed potato system supplies about $1.3 \%$ of the total supply in Ethiopia.

2.8. Seed Plot Technique (SPT): A tool that may play a vital role to increase quality seed production at farmers' level.
To increase the national average yield by increasing the quality of informally produced seeds and their supply to farmers, SPT as an informal system may play vital role in this regard. For quality seed production, TCRC of BARI has given attention to SPT. It shows better performances in producing quality seed potatoes in farmers field (Begum et al., 2013). Following this method, seed potato can be produced with very low disease incidence (virus $0.42 \%$ and scab infection $7.0 \%$ ) up to subsequent two generations and can be used as seed maximum for $3^{\text {rd }}$ generations without much loss of yield (Hossain and Ali, 1999; Anonymous, 2007; Anonymous, 2009; Hossain et al., 2011b). Some important steps of seed plot techniques are:

- Use of disease free HYV seed potato (Foundation seed).

- Early planting (within 15 November).

- Use of whole tuber with $60 \times 25 \mathrm{~cm}$ spacing.

- Soil treatment with stable bleaching powder.

- Seed treatment with boric acid (3\%)

- Use of isolation distance (at least 30m from ware potato or other solanceous crops).

- Roughing of infected plants, dissimilar plants etc.

- Use of insecticides, fungicides for aphid vector and fungal diseases.

- Potato haulm killing at 80 days after planting (DAP) or 15 Days before harvest.

- Sorting and storing of seed tubers in the cold storage for next year use etc.

\subsection{Potato seed standard in Bangladesh}

In Bangladesh, seeds are classified in four groups: a) Breeder's seed, b) Foundation seed, c) Certified seed and d) Truthfully labeled seed. The health standards of breeder seed, foundation seed and certified seed is inspected by a standing committee in the fields of seed potato crops, and also seed potato after harvest. The SCA is also involved in the seed inspection committee. The main considerations of the present seed certification of both seed and field standards for certified seed potato are given in Table 2 . Quality of certified seed potatoes is monitored and regulated by Seed Certification Agency (SCA) as approved by the National Seed Board. 


\subsection{Problems and challenges in seed potato production and supply systems in Bangladesh}

Less availability of quality seeds, fertilizer and pesticide, lack of knowledge on better farming practices, lack of storage systems (only 400 refrigerated cold storages are available) and finally, low investment capacity of the farmers are some of the major challenges in seed potato production and supply systems in Bangladesh. Hossain et al. (2011b) in a study found lack of quality seed and pest management as the main problems. However, the followings are the major problems in seed potato production and supply systems in Bangladesh (Hanemann and Ahmed, 2007; WOCSPPPCVA, 2008; BARI, 2009; Uddin et al., 2010; Hossain et al., 2011b; Shaheb et al., 2013; Mian et al., 2013).

- Lack of quality seed potato

- Disease problem especially late blight (Hossain, 1997), viruses etc.

- Insects problem especially aphid infestation that helps to disseminate virus diseases to potato plants.

- High price of quality seed potato

- Lack of knowledge on quality seed potato production

- Seed storage problem

- High price of the inputs (fertilizer, pesticides etc.)

- Lack of irrigation facilities and/or availability

- Unavailability of seed potato in proper time

- Marketing problem

- Short duration of winter season

- High transport costs

- Lack of educated labour (Rashid, 2001), etc. In addition, there are some other problems that can be frequently identified. These are lack of ready market, lack of reliable marketing information, exploitation by middlemen, lack of modernization of agriculture, low level of industrialization and so on. The linkages between public and private sectors for sustainable quality seed development program are lacking. Insufficient of trained manpower and the co-ordination at different levels for formal seed production is also poor. However, the major constraints to potato production in Asia are the inadequate supply of reasonably priced, good quality seed potatoes of the desired varieties (Rasco and Aromin, 1994; Vrolijk, 1994; Schmiediche, 1995).

\subsection{Policy recommendations}

There are scopes for further improvement of the potato sector in Bangladesh through the use of quality seed potatoes, quality inputs including fertilizer, pesticides and proper crop management. A number of studies have addressed these issues along with possible recommendation for enhanced potato production (Fraley et al., 1983; Hanemann and Ahmed, 2007; Uddin et al., 2009; Uddin et al., 2010; Mian et al., 2013; Anonymous, 2014). However, to improve the situation the following steps can be taken:

1. Production and supply of quality seed potato should be increased through strengthening both private and public sectors enterprises.

2. Establishment of Tissue Culture Laboratory is more important to set up a regular and well organized system of seed multiplication. Tissue culture technology should be disseminated to remove viral diseases, so that farmers can get virus free potato plantlets which they can cultivate within net house for preventing insect vectors to produce quality seed potato.

3. Research institutes should take initiatives to develop high yielding disease resistance varieties of potato. Traditional storage systems may be improved through research so that the farmers can store potato comparatively longer period (3-6 months) with lower storage loss.

4. The cooperation and co-ordination between planting material producers and seed multipliers for formal seed production needs to be improved.

5. Seed certification agency needs to be strengthened and field inspection to be done timely and rigorously. Both field and seed standards need to be strongly monitored and followed. 
6. Concerned authorities and diffusion agencies should give proper attention to disseminate sustainable seed potato production technologies through arranging farmers training followed by establishing seed potato demonstration plots at farmers field adequately.

7. Seed potato growers should be given credit facilities in easy terms and conditions. Besides, sufficient cold storage facilities should be developed in potato producing areas for preservation of their seed potato by utilizing cooperative effort or public-private partnership approach.

8. Farmers can produce a healthy crop using the "Seed Plot Technique". Farmers and extension staff are to be trained through farmer field schools to improve their capability for healthy seed crop production through improved agro-techniques.

9. Low cost mechanical harvesters may be introduced for proper harvesting of potatoes to reduce pre and pro-harvesting losses.

10. Government should take necessary steps to provide agricultural inputs at low price and available in time.

11. Market infrastructure should be developed in terms of quick transportation, proper storage and other physical facilities.

12. The linkages among the private/NGOs, research and extension organizations for sustainable quality seed development program is to be strengthened.

13. Above all, social responsibility and ethics of the seed traders, private seed companies and farmers are crucial to strengthen seed potato production and supply system in country.

\section{Conclusions}

Potato is a developing industry in Bangladesh. There is a wide scope of increasing area and production of potato in the country with a little added efforts in sustainable production techniques and improvement of seed quality. Only $5-10 \%$ quality seeds are being used by the potato farmers in Bangladesh. Several steps are important for seed potato production and supply systems at different stages viz. varietal development, multiplication, processing, preservation and quality control. These are various processes which ultimately contribute to the good seed for production of good crop. In prioritizing different issues of agriculture, supply of quality seed to the farmers should be considered as a top priority issue. For increasing quality seed supply to the farmers, the whole seed system needs to be reviewed.

The capacity of both public and private sectors should be strengthened for the improvement of seed system. It has been scientifically proved and recognized that seeds are the focal point that can boost up crop yield and quality seeds alone can contribute to the increase of yield by $15-20 \%$. Thus, it can greatly help in achieving sustainable food security for the emerging population within the limited land, water and other agricultural resources. The information of this paper may help the policy makers, researchers, BADC, extension personnel, private seed companies, and entrepreneurs etc. to take necessary steps towards the sustainable seed potato production and supply system in Bangladesh.

\section{Acknowledgement}

The authors express their profound thanks to Centre for Development Innovation (CDI), Wageningen UR, The Netherlands for their efforts and contribution during several group tasks and discussion session of brain storming to find out the possible problems of seed potato production and supply systems in Bangladesh at the international training program held in June 2013, organized by CDI, WUR, The Netherlands.

\section{References}

Adane Hirpa., Meuwissen, M. P. M., Tesfaye, A., Lommen, W. J. M., Lansink, A. O., Tsegaye, A. and Struik, P. C. 2014. Analysis of Seed Potato Systems in Ethiopia. American. Journal of Potato Research, 87:537-552. DOI 10.1007/s12230-010-9164-1. 
Ahmad, K. U. 1977. Report on potato production in Bangladesh. International Potato Course: Production, Storage and Seed Technology. Report of Participants. International Agricultural Center, Wageningen, The Netherlands.

Ahmed, M. K. 2013. Seed potato production systems in Bangladesh. A country report presented at international training programme on seed potato technology, certification and supply systems at CDI, WUR, The Netherlands (3 June-28 June 2013).

Anonymous, 2014. Potato crop vulnerability 2014, v 01-29-14. pp-35 (http://www.arsgrin.gov/npgs/cgc_reports/potatovuln2014 .pdf) (Last assessed on 17 November 2014).

Anonymous, 2007. Annual report on tuber crop improvement, Tuber Crop Research Centre, Bangladesh Agricultural Research Institute (BARI), Gazipur.

Anonymous, 2008. "Bangladesh Potato Campaign 2008. Alu Khan Krishak Bachan" Souvenir published at conference on potato campaign (May 07-09, 2008) organized by Ministry of Agriculture, FAO and CSD, Bangladesh at Bangladesh-China Friendship Conference Centre (BCFCC), Dhaka, 18 p.

Anonymous, 2009. Annual report on tuber crop improvement, Tuber Crop Research Centre, Bangladesh Agricultural Research Institute (BARI), Gazipur.

Azimuddin, M., Alam, Q. M. and Baset, M.A. 2009. Potato for food security in Bangladesh. International Journal of Sustainable Crop Production, 4(1):94-99.

BADC, 2012. Annual report, 2011-12 of Bangladesh Agricultural Development Corporation, Monitoring Division, pp177.(http://www.badc.gov.bd/files/ar/ar11 _12.pdf).
BARI, 2014. About BARI. Published by Bangladesh Agricultural Research Institute (BARI), Gazipur, Bangladesh, 14 p.

BARI, 2009. Annual report ofTraining and Communication Wing, BARI, Joydebpur, Gazipur, 29-35 pp.

BBS, 2012. Statistical Year Book of Bangladesh, Bangladesh Statistics Division, Ministry of Planning, Govt. of the People's Republic of Bangladesh.

Begum, M. M., Goswami, B. K., Ahmed, K. U. and Noor, S. 2013. Farm level disease free improved seed potato production technology. Published by TCRC, BARI, Joydebpur, Gazipur, 1-48 pp.

CIP, 2009. Potatoes and sweet potatoes: providing food security. International Potato Center, Annual report 2008, 96 p.

CIP:WPA, 2009. International Potato Center: World Potato Atlas. Last assessed on 16 June'2014.https://research.cip.cgiar.org/co nfluence/display/wpa/Bangladesh.

FAO, 2010. FAOSTAT. http://faostat.fao.org

Fraley, R. T., Rogers, S. G., Horsch, R. B., Sanders, Flick, S. P., Adams, S. P., Bittner, V., Brand, L. A., Fink, C. L., Fry, J. S., Galluppi, G. R., Goldberg, S. B., Hoffman, N. L. and Woo, S. C. 1983. Expression of bacterial genes in plant cells. Proceeding of National. Academy of Science, USA 80: 4803-4807.

Getachew, T., and Mela, A. 2000. The role of SHDI in potato seed production in Ethiopia: Experience from Alemaya integrated rural development project. African Potato Association Conference Proceedings, 5: 109-112.

Gildemacher, P., Demo, P., Kinyae, P., Nyongesa, M. and Mundia, P. 2007. Selecting the best plants to improve seed potato. LEISA Magazine, 23(2): 10-11. 
Gildemacher, P., Demo, P., Barker, I., Kaguongo, W., Gebremedhin, W., Wagoire, W. W., Wakahiu, M., Leeuwis, C. and Struik, P. C. 2009. A description of seed potato systems in Kenya, Uganda and Ethiopia. American Journal of Potato Research, 86: 373-382.

Gildemacher, P., Geldermann, E. S., Borus, D., Demo, P., Kinyae, P., Mundia, P. and Struik, P. 2011. Seed potato quality improvement through positive selection by smallholder farmers in Kenya. Potato Research, 54: 253-266.

Hanemann L. P. and Ahmed, M. S. 2007. Constraints and opportunities facing the horticultural sector in Bangladesh. Abt Associates Inc., $66 \quad$ p. (http://www.abtassociates.com/reports/Ho rticulturalSectorInBangladesh.pdf).

Hossain, K. Z., Rayhan, S. J., Arif, M. N. and Rahman, M. N. 2011a. Developing Country Studies ISSN 2224-607X (Paper) ISSN 2225-0565 (Online), www.iiste.org., $1(2): 27-33$.

Hossain, M. 1997. Purification and Antiserum Production of Potato X and Y Viruses on the Development of late blight in selected potato (Solanum tuberosum L.) Genotypes. Ph. D. thesis, University of Philippines, Las Benos, Philippines.

Hossain, M. and Ali, M. S. 1999. Disease management of seed potatoes in Bangladesh. Proc. of the Regional Workshop on Informal/Formal Seed Potato Production in Bangladesh, held at BARI from 9-13 March, 1999.

Hossain, M., Dey, T. K., Akther, S., Bhuiyn, M. K. R., Hoque, M. A., Kundu, B. C., Hossain, M. A. and Begum, S. N. 2008. Activities and achievements of Tuber Crops Research Centre at a Glance. Bulletin published by the Tuber Crops Research Centre, BARI, Gazipur, 23 p.
Hossain, M., Hossain, M. I., Dey, T. K. and Kabir, K. H. 2011b. Disease free seed potato production through seed plot technique at farm level. Final report of a technology transfer project funded by BARC, Dhaka, 11 p.

Huda, M. N. 2001. Why Quality Seed? Reality \& Vision Bangladesh Context. Evergreen Printing and Packaging, Dhaka-1000, 9$156 \mathrm{pp}$.

Ilangantileke, S., Kadian, M. S. and Thakur, K. C. 2000. True potato seed technology in Bangladesh and India - the present status. In: Performance and Prospects of Hybrid True Potato Seed in South and Southeast Asia: Proceedings of the CIP-ADB Symposium on "Field Testing Hybrid TPS in the Lowland Tropics of Asia, (ed.) Keith O. Fuglie. Bogor, Indonesia, September 13-14, 2000. International Potato Center (CIP and Agency for Agricultural Research and Development (AARD), Indonesia.

ISAAA, 2010. Biotech potato reduces disease incidence and seed import in Bangladesh global knowledge. Center on Crop Biotechnology, International Service for the Acquisition of Agri-Biotech Applications, SE Asia Center. Published online on December 10, 2010 (http://www.isaaa.org).

Islam, M. A. 1983. Report on potato production in Bangladesh. International Potato Course: Production, storage and seed technology. International Agricultural Center, Wageningen, The Netherlands.

Islam, S. M. F., Anwar, M. M. and Manos, B. 2000. Potato production system in Bangladesh: resource use, productivity, efficiency and comparative profitability of true potato seed technology over traditional tuber technology. Acta Horticulture (ISHS), 536: 261-268. 
Johnson, S. B., Olsen, N., Rosen, C. and Spooner, D. M. 2010. Commercial potato production in North America. American Journal of Potato Research 87 suppl: 190. In: Potato crop vulnerability 2014, v 01-29-14. (http://www.arsgrin.gov/npgs/cgc_reports/potatovuln2014 .pdf).

Kadian, M. S., Ilangantileke, S. G. Jayasinghe, U., Hossain, A. E., Hossain, M. and Babu, A. G. C. 2000. Potato seed system in Bangladesh and Srilanka. Proc. Of the Global Conference of Potato, held at New Delhi 6-11 December, 1999, vol. 1, 690$697 \mathrm{pp}$.

Karim, M. R. 2009. Seed potato production through tissue culture technology. In Seminar Program arranged by Bangladesh Agricultural Development Corporation, Dhaka.

Khurana, S., Paul, M. and Garg, I. D. 2003. Potatoes in warm climates. In: Virus and virus-like diseases of major crops in developing countries. Gad Loebenstein and George Thottappilly (Eds). Kluwer Academic Publishers. Dordrecht, The Netherlands.

Lutaladio, N., Ortiz, O., Haverkort, A. and Caldiz, D. 2009. Sustainable potato production; guidelines for developing countries. FAO, Rome, Italy.

Lutaladio, N. B. and Castaldi, L. 2009. Potato: The hidden treasure. J. Food Comp. Anal. 22: 491-493. (http://cipotato.org/seedpotato-for-africa/\#sthash.0yLdU2eK.dpuf)

Mian, M. A. M., Hossain, T. M. B., Hossain, S., Kadian, M. S. and Hossain, M. 2013. Farmers' perception about variety development and abiotic stresses on potato cultivation in Bangladesh. Bangladesh Journal of Agricultural Research, 38(3): 401-416.

Mondal, M. R. I., Islam, M. S., Bhuiyan, A. J., Rahman, M. M., Alam, M. S. and
Rahman, H. H. 2011. Agrotecnology hand book (Part-1), $5^{\text {th }}$ edition. Bangladesh Agricultural Research Institute, Gazipur, Bangladesh.

Mulatu, E., Osman, E.I. and Etenesh, B. 2005. Improving potato seed tuber quality and producers' livelihoods in Hararghe, Eastern Ethiopia. Journal of New Seeds, $7(3): 31-56$.

NIVAA, 2011. The road to seed production (Brochure) NIVAA, Dem Haag. The Netherlands. www.nivaa.nl.

NIVAP, 2011. Netherlands catalogue of potato varieties. Peeten, H.M.G., Folkertsma, S., schipper, J.K., Baarveld, H.R and Klein, S. (Eds). Publisher NIVAP, Den Haag, The Netherlands. www.nivap.nl

Rasco, E. T. and Aromin, F. B. 1994. The Potato in its third frontier in Rasco E.T. and F.B. Aromin (Eds). 1994. Proceedings of the Fourth APA Triennial Conference APA, 1-24 pp.

Rashid, M. A. 2001. Crop cultivation practices: Input-out put relationship of major crops in Bangladesh. Agricultural Research Management Project, BARC, Dhaka.

Schmiediche, P. 1995. The production of seed Potatoes in South East Asia in Proceedings of an Industry Workshop. An Emerging Opportunity; The Export of Tropical Seed Potatoes to Asia. Curtin University.

Schulte-Geldermann, E., Gildemacher, P. R., and Struik, P. C. 2012. Improving seed health and seed performance by positive selection in three Kenyan potato varieties. American Journal of Potato Research (USA), $\quad$ 89(6): 429-437. http://dx.doi.org/10.1007/s12230-0129264-1.

Shaheb, M. R. 2013. Country paper on seed potato production, seed supply systems 
and challenges in Bangladesh. Presented at International Training Program on seed potato technology, certification and supply systems at CDI, WUR, The Netherlands.https:/teamsites.wur.nl/sites/c dicourses/seedpotatojune2013/stepages/ho me.aspx.

Shahriar, S. M., Hasan, M. K. and Kamruzzaman, M. 2013. Farm level potato (Solanum tuberosum L.) cultivation in some selected sites of Bangladesh. Bangladesh Journal of Agricultural Research, 38(3): 455-466.

Struik, P. C. and Wiersema, S. G. 2012. Seed potato technology. Wageningen Academic Publishers, PO Box 220, AE Wageningen, The Netherlands.

Struik, P. C. and Wiersema, S. G. 1999. Seed potato technology. Wageningen Press. PO Box 220, AE Wageningen, The Netherlands.

Thiele, G. 1998. Informal potato seed systems in the Andes: Why Are They Important and What Should We Do with Them? World Development, 27(1): 83-99. Elsevier Science Ltd. Great Britain.
Uddin, M. A., Alam, Q. M. and Baset, M. A. 2009. Potato for food security in Bangladesh, International Journal of sustainable Crop Production, 4(1): 94-99.

Uddin, M. A., Yasmin, S., Rahman, M. L., Hossain, S. M. B. and Choudhury, R. U. 2010. Challenges of potato cultivation in Bangladesh and developing digital databases of potato. Bangladesh Journal of Agricultural Research, 35(3): 453-463.

Vrolijk, B. 1994. Asian Potato Trade. Economic analysis of the international trade of potatoes and potato products To, From and Within Asia. PhD Thesis. Wageningen Agricultural University, The Netherlands, $53 \mathrm{pp}$.

Walker, T., Thiele, G., Suarez, V. and Crissman, C. 2011. Hindsight and foresight about potato production and consumption. Social Sciences Working Paper, International Potato Center (CIP), Lima, Peru.

WOCSPPPCVA, 2008. Synopsis of workshop on opportunities and challenges for sustainable production and protection of the potato crop in Vietnam and elsewhere in Asia. Dalat, Vietnam, 25-28 November 2008, 39 pp.

www.badc.gov.bd (Information on seed potato standard, last assessed on 27 May 2013). 